\title{
Students' Psychological Factors in SLA: A Dillema for Teachers of English
}

\author{
Langgeng Budianto
}

Email: lbudianto@indiana.edu

School of Education; W.W. Wright Eduation Biulding 201 N. Rose Avenue Bloomington, IN 45405-1006

Address: 500 South Park Ridge Rd, Apt. 8203 Bloomington, IN 47408

\begin{abstract}
This paper aims at describing psychological factors in language acquisition and learning for human being who learn second language acquisition. Stephens found that external factors such as the characteristic of teacher, class and school condition had consistently no relation with the success of learning foreign language. On the other hand, student's psychological conditions, as one of the internal factors, are potential to influence the foreign or second language acquisition. Psychological factor is a factor that is mentally or spiritually concerned with the aspects in students' acquisition. At least, four of many factors, such as anxiety, attitude, aptitude, and motivation influence the students' process of language acquisition. However, to cope the psychological problems of learning second language, Kando, D. suggests the five strategies for coping with language anxiety, among of them are preparation strategy, relaxation, positive thinking, peer, and labeled resignation. Therefore, in maximizing the result of second language acquisition, the five strategies illustrated by Kando are important as an alternative solution.
\end{abstract}

\section{Keywords}

Language Acquisition, Psychological Factors

\section{Introduction}

Language learning ultimately occurs in the mind of learner, mental structure or mechanisms process and organize the language which the learner is exposed. Looking at the phenomena of teaching and learning process in Indonesia, the problem which is commonly faced by the students is not only in term of linguistic problem, but it is also concerned with non linguistic problems. Besides, there are many factors that influence the success of learning, especially learning English as a foreign language. Slameto (1987) states that those factors can be classified into two groups, namely internal and external factors. The internal factor commonly involves the internal aspects of the learners such as physics, psychology, and anxiety, while external factor may cover any aspects out of the learners point of view, such as environment, school, family, etc.

Some current studies in language acquisition suggest positive views towards the importance of exposure to linguistic input in promoting acquisition. It implies that teachers are required to use the target language and provide input as much as possible since the learners are at initial stages. In practice, however, to use the target language in classroom process teachers are not free from dilemma, particularly when they are to teach beginners who still have low language proficiency. The dilemma is that, on the one hand teachers are required to use the target language, on the other, the learners still have inadequate language proficiency. Therefore, teachers are required to modify their language in such a way in order to be appropriate with the level of the learner's proficiency. What characteristics does teacher's language consist of when they are in such dilemma? That question has led to the existence of the present study.

Stephens (in Ria; 1987) found that external factors such as the characteristic of teacher, class and school condition had consistently no relation with the success of learning foreign language. On the other hand, student's psychological conditions, as one of the internal factors, were potential to influence the foreign or second language acquisition. Saha (1983) says that the most important factor influences the result of study is the students' characteristic themselves. Samimy and Tabuse (1992) agree that affective variables such as attitude and motivation play a strong role in determining students' linguistic 
performance in class. Oxford (in Shumim; 1997) adds that the affective side of the learner is probably one of the most important influences on language learning success or failure. The affective factors which are dominantly related to second language or foreign language learning are anxiety, attitude, aptitude, and motivation.

In this paper, the discussions are focused on how the psychological problems such as anxiety, attitude, aptitude, and motivation influence the students in learning English as a foreign language.

\section{Some Students' Psychological Factors in SLA}

Psychological factor is a factor that is mentally or spiritually concerned with the aspects in students' acquisition. It, at least, involves four of many factors, such as anxiety, attitude, aptitude, and motivation since they have been proved through some research findings.

\section{Anxiety}

Language anxiety is conceptualized as a situationspecific personality trait having two psychological components: emotional arousal and negative self-related cognition (MacIntryre in David:148). He further statad that these components ostensibly interfere with behavior instrumental to language learning, and are more intense in people who are dispositionally high in language anxiety. In line with David, Brown (1994) states that second or foreign language learning is a complex task that is susceptible to human anxiety, which is associated with feelings of uneasiness, frustration, self-doubt, and apprehension. In addition, Shumin (1997) found that the anxiety provoked her students in speaking English in China. It happened especially when they speak the target language in public, especially in front of native speakers. Sometimes extreme anxiety occurs when English Foreign Language (EFL) leaner become tonguetired or lost for words in expected situation, which often leads to discouragement and general sense of failure. Brown (1994) says that adults, unlike children, are concerned with how they are judged by others. They are very cautious about making errors in what they say, for making errors would be a public display of ignorance that would be an obvious occasion of "losing face" in some cultures such as in Indonesia, China and in other oriental countries. Clearly, the sensitivity of adult learners to making mistakes has been the explanation for their inability to speak English without hesitation.
Certain personality patterns will cause students to reach negatively to our verbal instructions and command. For example, students with high anxiety levels (uptight people) do not respond to motivational instructions such as "it is important that you do well," and "this will count double on your grade, " etc. as well as people with lower anxiety levels. Most personalities respond more positively to praise than to punishment and blame. Thus, avoid saying "why can't you learn this? It is so simple. My other classes didn't have any trouble with it at all. Tomorrow you take the test whether you know it or not, "otherwise the students will get frustrated (Smith; 1975).

\section{Aptitude}

Aptitude is defined as the capacity to learn possessed by someone (Higard, in Slameto; 1988). Further, Skehan (1989) states that "aptitude is consistently the best predictor of language learning success". The existence of aptitude in foreign or second language learning is very influential. There is evidence in the research literature that some individuals have an exceptional "aptitude" for language learning. A research done by Carroll (in Oller, 1977) to American student who took major in French, German, Russian, and Spanish shows that language aptitude is significantly associated with success in foreign language study. Obler (in Bartley: 1980) reports that a man, whom she calls CJ (initial name), has such special ability. $\mathrm{CJ}$ is a native speaker of English who grew up in an English home. His first true experience with a second language came the age of 15 with formal instruction in French. CJ also studied German, Spanish, and Latin while in high school. At age 20, he made a brief visit to Germany. CJ reported that just hearing German spoken for a short time was enough for him to recover the German he had learned in school. Later, CJ worked in Morocco where he reported learning Moroccan Arabic through both formal instruction and informal immersion. He also spent some time in Spain and Italy, where he apparently "picked up" both Spanish and Italian in a matter of weeks. There may be few learners like CJ, but research does show that human beings exhibit a wide range of aptitude for learning a second language.

The work of Carroll and Pimsleur in Developing Foreign Language Aptitude Tests (in Smith, 1975) has provided extensive evidence that there is a special factor or an aptitude for learning a foreign language. They identify four factors serve as components of an aptitude for foreign languages as follows: 
a) Phonetic decoding. This is an ability to discriminate among foreign sounds and to encode them in a manner such that they can be recalled later. This would certainly seem to be a skill involved in successful second language learning.

b) Grammatical sensitivity. This is the ability to recognize the function that words fulfill in sentences. It does not measure the ability to name or describe the function, but rather the ability to discern whether or not words in different sentences perform the same function. It appears logical that skills in being able to do this helps in learning another language.

c) Inductive language-learning ability. This is the ability to infer, induce or abduct rules or generalization about language from sample of the language. A learner proficient in this ability is less reliance on well-presented rules or generalizations from a teacher or materials.

d) Memory and Learning. Originally this was phrased in terms of association: the ability to make and recall associations between words and phrases in a native language and a second language. It is not so clear whether this type of association playa a major role in language learning, but memory for language materials is clearly important.

They claim two of these factors, phonetic decoding and memory and learning, do not correlate highly with intelligence. Foreignlanguage learners may be better endowed in one or two of the factors. Certainly the variance in aptitude that exists among foreign-language learners is as great as that of shoe size. In other words, every foreign language learner has different number of aptitude. It varies from one to another.

\section{Attitude}

Attitude is defined as a manner of acting, feeling or thinking that shows one's disposition, opinion, etc. (Webster, 1996). Attitude develops as a result of experiences, both direct and vicarious, which are greatly influenced by people in the immediate environment: parents, teachers, peers; attitude toward self, in the target language and the people who speak it (peers in particular), and the teacher (Ameto, 1988). Brown (1980) assumes that if we have a positive attitude toward the language learned, we will try hard to learn that language seriously.
Some studies show that there is a positive relationship between attitude and second language acquisition. Gardner and Lambert (in Ameto:1988) found that the learner ethnocentric tendencies and his attitude toward the target language determines the success in learning the new language. In 1949 Jones (in Oller, 1977) published a pioneering study on the topic attitude toward learning a second language and a year later he reported results showing positive correlation between measures of attitude and attainment in Welsh-studied as a second language. One of his conclusion was that the strength of the correlation between attitude and attainment tended to increase.

Student's attitude toward the language he learns may vary. He may feel exited, happy, confident, and adequate, or he may feel bored, frustrated, angry, and in adequate. For example, when he becomes confused in a pattern drill, he may feel frustrated; after having repeated the same sentence a number of times, he may bored; while composing a conversation with a fellow students, he may feel exited and elated. Having been handed back a test he failed, he may feel angry and inadequate. Those conditions may influence student to decide whether he participates actively in the class or not; he does his homework or not; he continues his foreign language study or drops it.

We are as English teachers should have a big concern on the unfavorable students' attitudes by finding the causes and the possible solutions. Smith (1975) classifies some unfavorable students' attitude on foreign language learning as Dumbbell attitude, Irrelevant attitude, and Bored attitude.

\section{The Dumbbell Attitude}

Probably one of the most prevalent negative aptitudes is what Smith calls as the "Dumbbell attitude". The students meet with nothing but failure. He sees himself as a "dumbbell" which may be something totally new for him, and certainly totally disagreeable. Pimsleur's study on underachievement in foreign language indicates that nearly 20 percent of FL students can be placed in this category, that is, the grade they get in foreign language is at one letter-grade lower that what they ordinarily get in other subjects. No one's ego can endure consistent failure. The student will naturally react negatively to the cause of his feelings of stupidity and inadequacy. He will dislike foreign languages. 


\section{The Irrelevant Attitude}

Another kind of attitude is what Smith calls "irregular attitude". The students with this attitude may have enrolled in foreign language class for strictly utilitarian reasons: it meets requirement, it brings him prestige or recognition in the community or among friends, it has certain vocational applications. Since he has little or no interest in the study of language, he may become impatient with the slow process of language acquisition and feel that the meager returns he is getting for all the effort expended are not meeting his expectations. He does not see the connection between what goes on in the foreign language class and the practical demands of his existence now or later.

\section{The Bored Attitude}

There is the uninterested, bored attitude that students with this attitude find it difficult to tolerate the routine that often settles in the classroom. When we ask any youngster what he learned in school today, the response given may "oh, the same old stuff" - in spite of the fact that it probably was not the same old stuff. It was just presented in the same way. Routine is expedient and often necessary for the overworked teacher who has neither time nor energy to innovate and to be creative.

\section{Motivation}

A social psychological factor frequently used to account for differential success in learning a second languge is motivation. This has an intuitive appeal. It makes sense that individuals who are motivated will learn another language faster and to a greater degree. Furthermore, numerous studies have provided statistical evidence that indicates that motivation is a predictor language-learning success (Gass, 1994). Gardner, in early work with Lambert and in later work with colleague at the University of Western Ontario, is the primary figure in the field of motivation in second language learning. " Motivation involves four aspects, a goal, effortful behavior, a desire to attain the goal and favorable attitute toward the activity in question" (Gardner, 1985). He differentiates between two types of motivation: integrative and instrumental. Integrative motivation refers to motivation that comes from a desire to integrate with the target language (TL) community; instrumental motivation comes from the rewards that might come from the learning (e.g. learning English in order to study mathematics in English-speaking university). Integrative motivation is hypothesized to be a better predictor of a second language success than instrumental motivation.

Meanwhile, Nation (in Huerta, 1979) devides motivation into primary motivation and secondary motivation. Primary motivation in which the interest comes from the learner himself, and not from outside the learner. To get this type of response from learners should be a must for all teachers. If the teacher can make the learners fell that they want to learn, that they are interested, the subject they are studying is exciting. Secondary motivation refers to the feeling of the learners that they must learn in order to pass a test, to avoid punishment, or to please his parents or teachers.

Fostering student's motivation to attain a foreign language achievement is very important. Finocchiaro (in O'Brien, 1977) advises teachers for fostering motivation as follows:

a) Freedom for fear: e.g. Learners should not be embarrassed if they have not done their assignment, if they make error in production, or if they cannot response immediately.

b) Understanding: e.g. Teachers must consider the socio-economic, cultural, and emotional background of the learners in order to help them maintain their pride in themselves.

c) Experiences: e.g. Learners must engage in a wide variety of activities in order to fulfill their need for thinking, learning, doing, or choosing.

d) Love: e.g. The teacher often has to take the role of a substitute parents and be aware of the hunger for affection of the learner who, rightly or wrongly, feels rejected by family or peers.

e) Belonging: e.g. Learners should participate with the class "community" in all facets of planning and decision making during the learning process.

f) Achievement and Actualization: e.g. Learners should be helped to perfect today what they might have been able to do only haltingly yesterday. They should receive continuous feedback of their own aspirations and ideas.

g) Grouping and Individualization: e.g. The teacher should be aware of the level at which each student is capable of operating at any moment in time, of his or her optimal way of learning, of the time he or she needs to learn 
and should gear classroom group and individual activities to take all these factors into account.

h) Success: e.g. The learners should experience numerous small intermediate successes and attain short term goals which will then motivate him or her to continue working toward individual, school, community, or nation-wide goals (depending on his or her age level and learning).

To extent motivation demands a well-balanced combination of the teachers art and skills. It is not enough for the teacher to make use of psychological principles of whether schools to motivate learners. The teacher can also foster motivation through his or her own sense of security resulting from adequate linguistic and methodological preparation (O’Brien, 1977).

As a whole, motivation in second language acquisition may be thought as the incentive, the need, or the desire that the learner feels to learn the second language. With regard of motivation, like all type of learning, motivation to learn a language is undoubtedly important in the success or lack of success in learning. According to Dulay (1982) there are three kind of motivations affect language acquisition: integrative motivation, instrumental motivation, and social group identification.

Integrative motivation may be defined as the desire to achieve proficiency in a new language in order to participate in the life of the community that speakers the language. It reflects a sincere and personal interest in the people and culture represented by the other group (Gardner and Lambert, 1972:132). The problem occures in this case is that if the learner feels that he is able to communicative with the intended society, usually he will stop to learn the language although he acquisition is considered low and not enough for standard of acquisition.

Gardner and Lambert further states that instrumental motivation is different from integrative motivation. Instrumental motivation may be defined as a desire to achieve proficiency in a new language for utilitarian reasons, such as getting a job. It reflects the practical values and advantages of learning a new language group (Gardner and Lambert, 1972:132). In line with Gardner and Lambert ideas, Segaran (1981) states that attitude and motivation are related to achievement in second language learning, and that integrative motivation orientation, in particular, makes more successful learning than motivation of instrumental orientation. Students whose motivation to study a language as an instrument to get something, those who is categorized in having instrumental motivation, tend to have lower achievement than students whose integrative motivation.

Social group identification may be defined as the desire to acquire proficiency in a language or language variety spoken by a social group with which the learner identify. Conversely, the lack of identification with a given group may result in a leaner not wanting to acquire the language or language variety spoken by that group. Duley (1982) states that social group identification motive is similar to the integrative motive, but in our interpretation, goes beyond it. Learner with an integrative motive for learning a new language would wish to participate in the social or cultural life of the target language speakers while retaining their identification with their own native language group.

\section{Approaches to Helping Students to Cope}

Kondo, D. (2004:249) stated that when people are confronted with a situation that they think will make them anxious, the most expected response is to avoid the situation and thus avoid the discomfort. However, in most language acquisition, avoidance is not a viable option; they are expected to find some way to cope with the anxiety. Three intervention approaches provide the basis for considering the types of strategies that the students use to cope with their language anxiety. If they think that their cognition (worry, preoccupations, and concerns) creates the anxiety, they may attempt to suppress or alter the thought processes related to language learning. Those who believe that emotional arousal (physiological responsiveness) is the primary concern may take steps to alleviate bodily reactions and tension. If students presume that anxiety occures because they lack the requisite skills, they percieve that their anxiety is too much to cope with, they may not invest enough effort to reduce the anxiety.

Kando, D. suggests further that there are five strategies for coping with language anxiety, among of them are preparation strategy, relaxation, positive thinking, peer, and labeled resignation. The first category, preparation, refers to attempts at controlling the impending threat by improving learning and study strategies (e.g. studying hard, trying to obtain good summaries of lucture notes). Use of the these strategies would be expected to increase students' subjectively estimated mastery of the subject matter, and hence reduce the anxiety associated with the language class. 
The second category, relaxition, involves tactics that aim at reducing somatic anxiety symptomes. Typical terms are "I take a deep breath and I try to calm down". The third category, positive thinking, is characterized by it its palliative function of suppressing problematic cognitive process that underlie students' anxiety (e.g. imagining oneself giving a great performance, trying to enjoy the tension). These strategies are intended to divert attention from the stressful to possitive and pleasant cues, and bring relief to the anxious student.

The fouth category, peer seeking, is distinguished by students' willingness to look for other students who seem to have trouble understanding the class and/or controlling their anxiety. For the anxious students, the realization that others are having the same problem may serve as a source of emotional regulation by social comparison. The final strategy is labeled resignation. This category is characterized by students' reluctance to do anything to alleviate their language anxiety (e.g. giving up, sleeping in class). Students reporting examples of resignation seem on minimizing the impact of anxiety by refusing to face the problem.

\section{Conclusion}

The description about student's psychological factors, such as anxiety, aptitute, attitude, and motivation contribute the success in learning English as a second language. Those factors have a significant evidence proved by some research findings mentioned earlier. In addition, three kind of motivations also affect language acquisition: integrative motivation, instrumental motivation, and social group identification.

Five strategies are significantly considered for coping with language anxiety, among of them are preparation strategy, relaxation, positive thinking, peer, and labeled resignation. Preparation, refers to attempts at controlling the impending threat by improving learning and study strategies, relaxition, involves tactics that aim at reducing somatic anxiety symptomes, positive thinking, is characterized by it its palliative function of suppressing problematic cognitive process that underlie students' anxiety, peer seeking, is distinguished by students' willingness to look for other students who seem to have trouble understanding the class and/or controlling their anxiety, and students' reluctance to do anything to alleviate their language anxiety. Finally, to maximize the result of second language acquisition, the five strategies illustrated above are important as an alternative solution for the foreign language teachers. And, it is necessary for the second language teachers to have a great concern to the student's psychological factors during the process of language acquisition.

\section{REFERENCES}

Ameto, P. 1988. Making It Happens: Interaction in the Second Language Classroom. New York: Longman.

Bartly, D. 1990. Factors Affectings Second Language Learning. Foreign Language Learning, Vol. 29, No. 2, August.

Brown, H. D. 1981. Affecting Second Language Learning: The Second Language Classroom. Oxford: Oxford University Press.

Dulay, B. 1992. Internal Processing. Language Two.

Gass, S \& Slinker, L. 1994. Second Language Acquisition: An Introduction Course. New Jersey: Lawrence Erlbaum Associate Publisher.

Kondo, D. 2004. Strategies for Coping with Language Anxiety: The Case of Students of English in Japan. ELT Journal. Vol. 58, No. 3, July.

O’ Brien, M. C. 1977. Motivation: A Historical Prospective. In M. Burt, H. Dulay and Finocchiaro, View Point on English as A Second Language.

Olliver, J. W. 1977. Attitude Variables toward Second Language Learning. New Mexico: University of New Mexico Press. 
Ria, Rum. 1987. Study Tentang Test masuk Bahasa Inggris PPIV Tahun 1983 dan Test Bakat Bahasa dengan Prestasi Belajar Bahasa Inggris IKIP Malang. Malang: IKIP Malang.

Saha, Lawrence J. 1983. Social Structure and Teacher Effects on Academic Achievement: A Comparative Analysis. Comparative Education Review. Vol. 27 No. 1.

Samimy, K.K. \& Tabuse, M. 1992. Affective Variables and A Less Commonly Taught Language: A Study in Beginning Japanese Classes. Language Learning. Vol. 42, No.3, September.

Schumim, K. 1997. Factors to Consider: Developing Adult EFL Students' Speaking Ability. Forum Journal: Vol. 35, No. 3, July.

Segaran, C. 1981. Problem of Learning English as Second Language. Singapore: Singapore University Press for SEAMEO Regional Language Center.

Slameto. 1988. Belajar dan Factor-Faktor yang Mempengaruhinya. Jakarta: Rineka Cipta.

Smith, Alfred N. 1975. The Importance of Attitude in Foreign Language Learning. Forum Journal, Vol. 13, No. $1 \& 2$. 